\title{
JUVENILE ANALYSED BASED ON THE ASPECT OF MORALITY ON THE MOVIE “ALPHA DOG” BY NICK CASSAVETES
}

\section{Christanto Dwi Nugroho}

\author{
Program Studi Informatika, Fakultas Teknik dan Ilmu Komputer \\ Universitas Indraprasta PGRI \\ christantodwinugroho@yahoo.com
}

\begin{abstract}
Abstrak
Penelitian ini dimaksudkan untuk mengetahui aspek moralitas dari film "Alpha Dog" oleh Nick Cassavetes, untuk mengetahui bentuk dan fungsi bahasa yang menggambarkan moral dan penggunaan bahasa yang menyuguhkan karakter baik dan buruk. Menggunakan deskriptif kualitatif, setelah dianalisa, penulis menyimpulkan bahwa karakter buruk lebih dominan daripada karakter baik. Pada asumsi awal bahasa pembentukan karakter awal ada ditangan orang tua. Karakter baik tidak frontal, tidak diberi/diajarkan dari pertumbuhan generasi, tapi perpaduan ajaran orang tua ditentukan dalam tiap pertumbuhan khususnya dalam kondisi "labil" anak tersebut dalam pengawasan mereka dari pengaruh kenakalan. Kenakalan remaja tampak mudah mempengaruhi remaja dan tampaknya tidak mudah ditangani, terlebih merupakan sesuatu yang membahayakan bangsa, jika tidak ditangani oleh orang tua dan masyarakat.
\end{abstract}

Kata Kunci: kenakalan remaja, moral, alpha dog.

\begin{abstract}
This study is supposed to know the aspect of morality on the movie "Alpha Dog" by Nick Cassavetes, to know how the form and the function of language use for describing of moral and the use of language to present good and bad character using descriptive qualitative. Having been analyzed the writer comes to the conclusion that bad moral is dominant comparing to good moral. Final the main of character building is parent hands, that good character its part is frontal not to be given from generation but the parents companion is needed is every process of growth especially in the "labil": condition of kids protected then from juvenile delinquencies. Juvenile delinquency look easy to spend out for the youth, and not to easy to care but it can be one of the danger of a nation, if it is not well cared by parent and society growth.
\end{abstract}

Keywords: Juvenille delinquency, morality, alpha dog

\section{INTRODUCTION}

Delinquency is general term for the youth at the present time this must be having full attention of parents, environment or schools. One of the disadvantages is ignoring to use of marijuana or narcotic. Whatever the roof of nation is the young generation it is hoped that they are responsible to drive up the nation or countries and it is expected that they have to have good mental characters.

Related to the need, above the writer wants to analyze an moral example of moral attitude from the film Alpha Dog. This is the film taken from real life written by Nick Cassavetes.

Historically, kid's brothers in the process of the growth had fallen in the debt. This film is not only 
entertained the audience / society but also the picture of life for them, we will take good things from it. It can happen in the daily life and it can't happen. It is the mirror of the growth of society. This film can be the mirror of how in the danger of smoking, drugs, or other kinds like marijuana, which may create juvenile delinquency.

The writer would like to analyze what aggressive reaction shown in this film played by the characters and would like to know how the end of film.

After watching Alpha Dog film, the writer may identified that there are morality aspects in her life, good and bad moral as the message that given by the film. The objective researches are:

1. By looking at the film, the audience may get the picture how to lead and guide the young or kids in the process of the growth. The character of the main character may happen in the daily life; he has good character, smart, diligent, friendly, smooth, obedient and always has positive thinking.

2. To enrich and enlarge writer about how to protect the young toward bad morality that nowadays known as juvenile delinquency.

3. As develop of learning and enjoying English words.

4. Be able to enlarge education field provided for children.

\section{- The Definition of literature}

1. Literature is a verbal art, or art which is made by an author by selecting, ordering and interpreting life experience to create a structure of fictional world through written or spoken words as its medium (Cambridge Advanced Learner's Dictionary, 2003)
2. Literature is a potential cause of experience (Welleck and Warrren, 2003:150)

3. Literature is the 'belles letters', or the aesthetic or elegant writing (poetry, fiction, or another imaginative written work which is intended to be enjoyed for its own sake rather than for a purpose of imparting information or instruction (Encyclopedia Britannia Ready Reference 2007)

\section{- Film}

The role of the film nowadays undeniably cannot be separated from people live. It can be as an entertainment or even as a medium to transfer the idea to society. Consequently, the society will probably follow that kind of the idea in that film which is covered with a good scenario and plot. For example, when the content of it is about a struggle of life with full of conflict, it is able to give inspiration for the viewers how to survive in life based on watching it. Moreover, as the story is taken from the true life, it becomes a special appeal for a viewer that is curious to know about what the story is and how it is served in a film. Some advantages that can be obtained by the viewers by watching it from the true story is the logical way which can be applied in their life.

From the story above which is taken from the actual life and packaged in a film that its functions as an entertainment, and also as a media to learn about humans character through the roles of the characters, it is inevitable that the role of film is inseparable from human life. People make it as a part of their live including as an 
entertainment, inspiration, and education. Regarding with this, the writer uses a film as an object of analysis. There are some definitions related to the film from some following sources:

1. Effendy (2000: 207) "Teknik perfilman, baik peralatannya maupun pengaturannya telah berhasil menampilkan gambargambar yang semakin mendekati kenyataan. Dalam suasana gelap dalam bioskop, penonton menyaksikan suatu cerita yang seolah-olah benar-benar terjadi dihadapannya." It can be said that to make a film there are certain techniques that support a good film in result while it is being played in the darkness, in a cinema, the viewer feels as if it were real happening in front of them.

According to Effendy
(2000: 201) "Film adalah
gambaran teatrikal yang
diproduksi secara khusus untuk
dipertunjukkan di gedung-
gedung bioskop dan televisi." It
means that there is a theaterical
element that is put in the film
and especially is referred to
show in cinemas.

\section{RESEARCH METHOD}

This is qualitative research for analyzing film which may tell the condition and situation of life in certain time on certain condition of culture of that situation" (Film: Aset Budaya Yang Harus Dilestarikan", Empire magazine hal 5-6). Human resources can be formed on the developing of the story that must be identified is moral attitude. Aminuddin, 2009:153 "Moral merupakan perbuatan atau tindakan yang dilakukan sesuai dengan ide-ide atau pendapat-pendapat umum yang diterima meliputi kesatuan sosial lingkungan-lingkungan tertentu" can be subjective or adjective. There are two approaches talking about moral about how society looks like as the value of moral which is applied by characters. Alpha Dog film by Nick Casavates has influenced audience. Sobur (2006:127) said that "kekuatan dan kemampuan film menjangkau banyak segmen sosial lantas membuat para ahli berpendapat bahwa film memiliki potensi untuk mempengaruhi khalayaknya". And it makes the writer tries to analyze the aspect of morality derived from the film Alpha Dog by Nick Cassavetes. A professional film produces how to describe the story adjust to the development of society. An artistic idea has to be how to let the audience interested in that film. This film is chosen, because the story happens in the daily life: this is real story in 1999 and being the film in 2006. Zack Mazuarty 15 years old which is adopted by Jesse James Hollywood in Calfornia.

\section{FINDINGS AND DISCUSSION}

The aspect of morality usually refers to understanding which is wrong and right, good and bad like mental, attitude and behave that can be accepted in society living. It can be very relative depend on the point of view of member of society.

\section{A. Good Morality Character}

\section{Zack Marzuky}

a) he is smart and responsible boy.

b) he is the victim of kidnapping.

c) when Jake asked him to take a nap, he was better to do his homework as this dialogue "Come on Zack lets go out and have some party in my house with friends and folks? Jack spoken.'I dont 
think so Jazk, I have to do my homework first maybe someother time", replied Zack. "You such a baby, Einstein ", said Jack his brother." (Zack Marzusky, 00:15:09)

d) he is smooth and obedient at the time of diving he still has positive thinking, he believes that his brother want to take him home as dialogue "Hey listen Zack, you have to go run as fast as you can I will try to safe your lifes and make something as a decoy, so you can run and out from this hill, "said Frankie. "No, Frankie, I will ok I will good and I'm sure my big brother will pick me and bring me home, is ok.", answer Zack. "No, Zack they going to kill you, open your eyes and realize this, Now run!" said Frankie again. " I dont want, thats not true, we go to the top of the hill because we want to dig hole for birds that Elvis Schmidt already killed, is ok Frankie I will do it I will dig for him, I will be ok. "Frankie, getting sad (because he knew Elvis's paln to kill Zack as revenge) and said, "Oh, man you are really such a nice boy, May Lord Jessus Protect your soul"

e) Then Elvis ask him to stand and Zack just obey evrything after that, he killed Zack with shooting gun in the top of the hill. Poor Zack, may he rest in piece. (Zack Marzusky, 107:15:09)

\section{B. Bad Morality}

\section{Johny Truelove}

a) A croupier of narcotics

b) $\mathrm{He}$ has free living uncontrollable make him in condition of drug and juvenile.

c) He tried to effort himself making small trade and the end he become the biggest trade in city. This is supported by his father as mentioned in the dialogue "Hey, Frankie I have a party in my house now come here and we have some fun with cook and weed too, fly high with those things as a dealer I have weed castle on my house now, said Jonny to Frankie. (Jonny TrueLove 00:03)

Table of Good and Bad Value

\section{Finding}

\begin{tabular}{|c|c|c|c|c|}
\hline \multirow{2}{*}{ Character } & \multirow{2}{*}{$\begin{array}{l}\text { Description of } \\
\text { data }\end{array}$} & \multicolumn{2}{|c|}{ Moral } & \multirow[t]{2}{*}{ note } \\
\hline & & good & bad & \\
\hline $\begin{array}{l}\text { Zack } \\
\text { Marzusky }\end{array}$ & $\begin{array}{l}\text { "Come on Zack } \\
\text { lets go out and } \\
\text { have some party } \\
\text { in my house with } \\
\text { friends and folks? } \\
\text { Jack spoken."I } \\
\text { dont think so } \\
\text { Jazk, I have to do } \\
\text { my homework } \\
\text { first maybe } \\
\text { someother time", } \\
\text { replied "Yack. "You such a } \\
\text { baby,Einstein ", } \\
\text { said Jack his } \\
\text { brother."(Zack } \\
\text { Marzusky, } \\
\text { O0:15:09) }\end{array}$ & $\sqrt{ }$ & & $\begin{array}{c}\text { By } \\
\text { Script }\end{array}$ \\
\hline $\begin{array}{l}\text { Zack } \\
\text { Marzusky }\end{array}$ & $\begin{array}{l}\text { "Dad is not } \\
\text { suppose to be my } \\
\text { job to fix } \\
\text { everything, I } \\
\text { mean I have to } \\
\text { taking care this } \\
\text { kid, what should I } \\
\text { clean everything? } \\
\text { "Frankie } \\
\text { begging. His } \\
\text { daddy answer } \\
\text { with angrily" "I } \\
\text { just dont care } \\
\text { clean everything }\end{array}$ & $\sqrt{ }$ & & $\begin{array}{c}\text { By } \\
\text { Script }\end{array}$ \\
\hline
\end{tabular}




\begin{tabular}{|c|c|c|c|}
\hline & $\begin{array}{l}\text { in this house!". } \\
\text { Zack then } \\
\text { replied, "Hey, } \\
\text { Frankie is ok } i \\
\text { will help you to } \\
\text { clean evrything I } \\
\text { like to clean } \\
\text { everything, don't } \\
\text { worry. "So he } \\
\text { cleaned } \\
\text { everything and he } \\
\text { is really such } \\
\text { nice boy say } \\
\text { Frankie as } \\
\text { witnessed in the } \\
\text { Police station. } \\
\text { (Zack Marzusky, } \\
\text { 80:15:01) }\end{array}$ & & \\
\hline $\begin{array}{l}\text { Zack } \\
\text { Marzusky }\end{array}$ & $\begin{array}{l}\text { "Hey listen Zack, } \\
\text { you have to go } \\
\text { run as fast as you } \\
\text { can I will try to } \\
\text { safe your lifes } \\
\text { and } \text { make } \\
\text { something as a } \\
\text { decoy, so you can } \\
\text { run and out from } \\
\text { this hill, "said } \\
\text { Frankie. "No, } \\
\text { Frankie, I will ok } \\
\text { I will good and } \\
\text { I'm sure my big } \\
\text { brother will pick } \\
\text { me and bring me } \\
\text { home, is ok.", } \\
\text { answer Zack. } \\
\text { "No, Zack they } \\
\text { going to kill you, } \\
\text { open your eyes } \\
\text { and realize this, } \\
\text { Now run!" said } \\
\text { Frankie again. " } \\
\text { I dont want, thats } \\
\text { not true, we go to } \\
\text { the top of the hill } \\
\text { because we want } \\
\text { to dig hole for } \\
\text { birds that Elvis } \\
\text { Schmidt already } \\
\text { killed, is ok } \\
\text { Frankie I will do } \\
\text { it I will dig for } \\
\text { him, I will be ok. } \\
\text { "Frankie, getting } \\
\text { sad (because he } \\
\text { knew Elvis's paln } \\
\text { to kill Zack as } \\
\text { revenge) and } \\
\text { said, "Oh, man } \\
\text { you are really } \\
\text { such a nice boy, } \\
\text { May Lord Jessus } \\
\text { Protect your } \\
\text { soul" } \\
\text { Then Elvis ask } \\
\text { him to stand and } \\
\text { Zack just obey } \\
\text { evrything after } \\
\text { that, he killed } \\
\text { Zack shooting gun in } \\
\text { the top of the hill. }\end{array}$ & $\sqrt{ }$ & $\begin{array}{l}\text { By } \\
\text { Script }\end{array}$ \\
\hline
\end{tabular}

\begin{tabular}{|c|c|c|c|}
\hline & $\begin{array}{l}\text { Poor Zack, may } \\
\text { he rest in piece. } \\
\text { (Zack Marzusky, } \\
\text { 107:15:09) }\end{array}$ & & \\
\hline $\begin{array}{l}\text { Jonny } \\
\text { TrueLove }\end{array}$ & $\begin{array}{l}\text { "Hey, Frankie I } \\
\text { have a party in } \\
\text { my house now } \\
\text { come here and } \\
\text { we have some fun } \\
\text { with cook and } \\
\text { weed too, fly high } \\
\text { with those things } \\
\text { as a dealer I have } \\
\text { weed castle on } \\
\text { my house now, } \\
\text { said Jonny to } \\
\text { Frankie. (Jonny } \\
\text { TrueLove 00:03) }\end{array}$ & $\sqrt{ }$ & $\begin{array}{l}\text { The } \\
\text { Script }\end{array}$ \\
\hline $\begin{array}{l}\text { Jonny } \\
\text { TrueLove }\end{array}$ & $\begin{array}{l}\text { "Jonny, I really } \\
\text { cant paid this } \\
\text { time but I really } \\
\text { need those things, } \\
\text { you know what I } \\
\text { mean so please } \\
\text { give it to me, } \\
\text { begging Jack } \\
\text { Marzusky (Zack's } \\
\text { Brother spoken to } \\
\text { Jonny). "Ok, but } \\
\text { I need something } \\
\text { special from you } \\
\text { as garantee your } \\
\text { guaranten } \\
\text { enjoy the weed, } \\
\text { how about that? } \\
\text { "answered } \\
\text { Jonny. "I dont } \\
\text { have nothing } \\
\text { now, I'm broke, } \\
\text { said Jack". "I } \\
\text { will not give you } \\
\text { anything, go } \\
\text { away from my } \\
\text { house, reguest } \\
\text { Jonny". Zack, } \\
\text { feels so depressed } \\
\text { because of less } \\
\text { the drugs, so } \\
\text { suddenly he } \\
\text { punched Jonny } \\
\text { right in his nose. } \\
\text { Jonny angry but } \\
\text { when he wanted } \\
\text { to shot Jack, their } \\
\text { friend splind } \\
\text { them. The next } \\
\text { day, Jonny meet } \\
\text { Zack (the victim } \\
\text { which Jack's } \\
\text { little brother) So } \\
\text { he Ransom him } \\
\text { until his brother } \\
\text { Jack paid his } \\
\text { money, (Jonny } \\
\text { Trulove } \\
\text { 37:09:05). }\end{array}$ & $\sqrt{ }$ & $\begin{array}{l}\text { The } \\
\text { Script }\end{array}$ \\
\hline $\begin{array}{l}\text { Jonny } \\
\text { TrueL }\end{array}$ & $\begin{array}{l}\text { "Dad, you have } \\
\text { to safe me from } \\
\text { here, I dont want }\end{array}$ & & \\
\hline
\end{tabular}




\begin{tabular}{|c|c|c|}
\hline $\begin{array}{l}\text { to put in the jail", } \\
\text { begging to his } \\
\text { father (Bruce } \\
\text { Willis actor). } \\
\text { "Son, I will help } \\
\text { you anything } \\
\text { even if it is } \\
\text { connection with } \\
\text { drugs I still help } \\
\text { you, but the } \\
\text { problem is you } \\
\text { kill an innocent } \\
\text { boy, hell no", } \\
\text { replied his daddy } \\
\text { to Jonny } \\
\text { TrueLove (Jonny } \\
\text { TrueLove } \\
\text { 120:01:07). } \\
\text { (Jonny TruLove } \\
\text { saying bad words } \\
\text { from start until } \\
\text { the end of this } \\
\text { movie) }\end{array}$ & $\sqrt{ }$ & $\begin{array}{l}\text { The } \\
\text { Script }\end{array}$ \\
\hline
\end{tabular}

Based on the above table then comes to the conclusion that the whole content of the story of Alpha Dog proves that bad character tend to present bad character, this is the picture which can be accepted in life.

\section{CONCLUSION}

1. Bad moral character is more dominant that good character its part is frontal no to be given from generation but the parents' companion is needed is every process of growth especially in the "labil": condition of kids protected then from juvenile delinquencies.
2. Good or bad moral in this story is evaluated the main character by words produced from manner, behavior, attitude, expression and action.

\section{REFERENCES}

Aminudin. (2009). Pengantar Apresiasi Karya Sastra. Bandung: Sinar Baru.

Cambridge Advanced Learner's Dictionary (3rd ed.). (2003). Cambridge, UK: Cambridge University Press.

Cassavetes, N. (2006). Alpha Dog. Film. Sidney Kimmel Entertainment.

Effendy, O. U. (2000). Ilmu, Teori, dan Filsafat Komunikasi. Bandung: PT. citra Aditya Bakti.

Sobur, A. (2006). Analisis Teks Media: Suatu Pengantar untuk analisis Wacana, Analisis Semiotika, dan Analisis Framing. Edisi Keempat. Bandung: PT Remaja Rosdakarya

Warren, W. (2003). The Objective Orientation. Boston Toronto: University Press. 